\title{
INVESTIGATION OF THE RELATIONSHIP BETWEEN WRITING SENSITIVITY AND WRITING ACHIEVEMENT ${ }^{1}$
}

\section{Özge AKKAYA ${ }^{2} \quad$ Ayşe Nur KUTLUCA CANBULAT ${ }^{3}$}

\begin{tabular}{|c|c|}
\hline Article Info & Abstract \\
\hline $\begin{array}{l}\quad \text { Keywords } \\
\text { Writing sensitivity } \\
\text { Writing achievement } \\
\text { Primary school teacher } \\
\text { candidates }\end{array}$ & $\begin{array}{l}\text { This study aimed to reveal the relationship between primary school } \\
\text { teacher candidates' writing sensitivity and writing achievement. This } \\
\text { quantitative study conducted with the relational survey model consisted } \\
\text { of } 575 \text { teacher candidates of two public universities. The data about } \\
\text { primary school teacher candidates' writing achievement were collected via } \\
\text { Rubric for Written Texts (RWT) with the help of written texts produced by } \\
\text { them and the Writing Sensitivity Scale (WSS). According to the findings } \\
\text { obtained, primary school teacher candidates had moderate writing }\end{array}$ \\
\hline $\begin{array}{l}\text { Received: } 31.07 .2021 \\
\text { Accepted: } 13.12 .2021 \\
\text { Published: } 28.12 .2021\end{array}$ & $\begin{array}{l}\text { sensitivity and writing achievement and there was a statistically significant } \\
\text { relationship between writing sensitivity and writing achievement. It can } \\
\text { be argued that writing sensitivity and writing achievement significantly } \\
\text { differ according to gender, while writing sensitivity does not significantly } \\
\text { differ based on year, writing achievement does. }\end{array}$ \\
\hline
\end{tabular}

Cited as APA: Akkaya, Ö., \& Kutluca Canbulat, A. N. (2021). Investigation of the relationship between writing sensitivity and writing achievement. International Journal of Current Approaches in Language, Education and Social Sciences (CALESS), 3(2), 222-243.

\section{Introduction}

As a language skill, writing is a skill that consists of processes related to obtaining and expressing information, which requires the coordination of many high-level mental skills acquired after listening, speaking, and reading skills. Writing is a dynamic process of dealing with an excessive number of simultaneous demands or constraints (Flower \& Hayes, 1980). During the writing process, the individual rearranges the information structured in his/her mind through processes such as examination, review, questioning, association, and control (Güneş, 2014). Writing skill is a skill that allows the information, emotions, and thoughts to be conveyed to the target audience in a more controlled way and provides the opportunity to configure the message through inspection. Because of this feature, it can be said that writing skill is a stronger

\footnotetext{
1 This paper was produced from the master's thesis written by the first author under the supervison of the second author.

2 (D) Ministry of National Education, Turkey, ozgeakkaya92@gmail.com

3 D Akdeniz University, Turkey, aysenur.canbulat@gmail.com
} 
language skill (Kutluca Canbulat, 2020), and it can be argued that writing skill is the product of a planned and controlled process.

It is known that the writer should possess accumulated knowledge about many different types of information about text content and discourse structure in his/her long-term memory to be able to write high-quality texts (Kellog, 2008). To produce texts, an individual's long-term memory should include declarative information about the subject and the reader as well as procedural information about what to say and how to say it (Pressley \& Harris, 2006). In this context, besides the information that the writer should have about the subject and the reader, he/she should also have information to establish the small-scale structure of the text to convey this knowledge such as reference, ellipsis, substitution, use of conjunctions, ensuring lexical coherence as well as operational information to establish its large-scale structure such as determining the protagonist, ensuring the unity and continuity of the text (Ülper \& Uzun, 2009).

According to Flower and Hayes Writing Model (1981), the act of writing is comprised three units: task environment, writer's long-term memory and writing process. Task environment and writer's long-term memory are the non-textual elements and the writing process is the textual element of writing. While producing the text, the writer is expected to use his/her prior knowledge of the subject he/she tends to write and the issues to be considered in the writing process. In other words, an individual's ability to produce texts of desired quality and to be a successful writer depends on his/her knowledge of what can be conveyed about the subject by considering the characteristics of readers; on his/her long-term memory about the topic, the reader, and the plan and on the writing process, which includes regularly observed phases such as planning, writing and review. However, it can be argued that the ability of the individual to successfully convey to the reader what he/she knows and wants to transfer is also related to the individual's sensitivity to writing.

Sensitivity means that the individual learns all the required elements, accumulates knowledge, and brings the knowledge to practice by diligently following all steps in the process from the start to the end. Writing sensitivity, on the other hand, defines the awareness, diligence, and sensitivity of the writer to fulfil all the necessary conditions for writing, in other words, to accurately utilize the processes of planning, drafting, checking the content, attending to spelling rules and rewriting. Writing sensitivity reefers to an individual's sensitivity to do planning by knowing that he/she should 
consider the characteristics of the text that will be written and to guide his / her texts within this plan (Bayat \& Şekercioğlu, 2014).

The writer's sensitivity during text production can be addressed in terms of textual elements such as the organization of ideas, coherence and cohesion, main idea and subordinate ideas, spelling and punctuation and non-textual elements such as communication atmosphere, the characteristics of the reader and the writer's need to feel appreciated through the text.

The individual's sensitivity to writing is thought to be related to metacognitive features (Bayat \& Şekercioğlu, 2014). Metacognition is a concept associated with skills such as being aware of the learning process, planning and choosing strategies, monitoring the learning process, correcting mistakes, checking whether the strategies are useful and changing the learning method and strategies when necessary (Özsoy \& Ataman, 2009; Özsoy, Memiş, \& Temur, 2009). The literature focuses on four metacognition skills: prediction, planning, monitoring, and evaluation (Desoete, Roeyers, \& Buysee, 2001; Desoete \& Roeyers, 2002; Lucangeli \& Cornoldi, 1997; Özsoy, 2010; Schraw \& Moshman, 1995; Özsoy \& Günindi, 2011). On the other hand, state that for a successful text, the writer should ask questions as to examine whether he/she should add or delete elements in the text based on his/her writing plan throughout the process of writing in addition to questions that will check who the text is for, what he/she knows about the topic, whether the available information is suitable for the reader or the purpose of the text, what kind of arrangement needs to be done to convey the purpose and whether the text has logical and coherent relationships during planning, drafting and reviewing of the text based on the criteria of textuality (cohesion, coherence, intentionality, acceptability, informativity, situationally and intertextuality) ( Englert et.al., 1991: Kaya \& Ateş, 2016). In this sense, the awareness of the individual to know what to do during the writing process, to practice what he/she knows and to review and evaluate what he/she has written can be considered as a metacognitive concept.

The writer is expected to fulfil the duties about textual and non-textual elements during text production. But does this expectation find its worth in writing performance? This needs to be assessed.

Writing skill may not develop in the same way in every individual and they cannot produce qualified texts. Therefore, written texts should be assessed in terms of quality. Assessment is a direct representation of what we value and how we assign that value, it says much about our identities as teachers, researchers, and theorists (Huot, 2003). When written language asked to be assessed, several questions must be addressed to determine what type of assessments should be used, and what the purpose of the 
assessment is, what information needed from the assessment is, how the assessment information is used and what assessment procedures are needed (Penner-Williams, Smith, \& Gartin 2009).

To assess written expression skill, the need for a valid and reliable writing assessment is of paramount importance. This can be provided by scoring rubrics and methods that define performance criteria on written expression, to better inform practice and learning (Dunsmuir, Kyriacou, Batuwitage, Hinson, Ingram, \& O'Sullivan, 2015). Rubrics used in the assessment of students' writing skills and abilities are often designed to evaluate components of composition such as form, thoroughness, grammar, syntax, and spelling. Rubrics may also be used to evaluate language proficiency, comprehension of subject matter, and/or cognitive development (East, 2006; Elliot, 2005; Huang, 2008; cited in Lovorn and Rezaei, 2011). Compared to other measuring tools analytic scoring system focuses on identified qualities of good writing and is judged on how many elements of good writing it contains (Huot, 1990). Thus, it can be said that analytical scoring provides more detailed information about students' writing skills.

\section{Purpose of the Study}

In this study, primary school teacher candidates' writing sensitivity and how their sensitivity can be observed in their writing performance was examined. Primary school teachers are the first teachers who will provide their students' cognitive awareness and sensitivity about writing by forming the basis of the writing skills and the requirements for the writing process. Revealing the relationship between primary school teacher candidates' writing sensitivity and their writing performance may be a predictor of how their students will contribute to the writing process. In other words, teacher candidates may affect their students' writing sensitivity and writing success in their professional careers. The fact that this relationship was determined during the pre-service education period may enable the educational experiences of the teacher candidates to improve their writing sensitivity. Thus, primary school teacher candidates who have gained sensitivity to writing can train more sensitive and successful students.

For this purpose, answers were sought to the main research problem and the subproblems as presented below.

Is there a meaningful relationship between primary school teacher candidates' writing sensitivity and their writing achievements? 


\section{Sub-problems}

1. What is primary school teacher candidates' level of writing sensitivity and writing achievement?

2. Does primary school teacher candidates' writing sensitivity differ according to gender and school year?

3. Do primary school teacher candidates' writing achievements differ according to gender and school year?

4. Do primary school teacher candidates' writing achievement levels differ based on their writing sensitivity?

5. Do primary school teacher candidates' writing achievement scores in the subdimensions of the Rubric for Written text differ based on gender and school year?

6. What is the relationship between primary school teacher candidates' writing sensitivity and writing achievement?

7. What is the relation between primary school teacher candidates' writing sensitivity and primary school teacher candidates' writing achievement scores in the subdimensions of the Rubric for Written text?

\section{Method}

\section{Research Model}

This quantitative research conducted by using the relational survey model aimed to determine the relationship between primary school teacher candidates' writing sensitivity and writing achievement according to gender and school year. The relational survey is a model that aims to determine the existence of co-variation between two or more variables. In the relational survey model, whether the variables change together; if there is a change, it is tried to determine how it happened (Karasar, 2011).

\section{Study Group}

The study group consisted of 575 teacher candidates studying at the Faculty of Education, Department of Elementary Education of two public universities. Of these participants, 161 were male and 414 were female; 286 and 147 were in their $1^{\text {st }}$ year, 141 in $2^{\text {nd }}$ year, 137 in $3^{\text {rd }}$ year and 150 were in their $4^{\text {th }}$ year.

\section{Data Collection Tool}

In the research process, with the permissions from both universities, the data were collected on a voluntary basis in one class hour on March 16 and 23 2017. Primary school teacher candidates were first asked to write a text titled "Teachers are the 
Architects of the Future" to measure their writing achievements and then they were asked to fill in the Writing Sensitivity Scale (WSS) and data collected through written texts were scored by using the Rubric for Written Texts (RWT) for determining writing achievement of the teacher candidates.

Writing Sensitivity Scale (WSS). The Writing Sensitivity Scale (WSS), developed by Bayat and Şekercioğlu (2014), consists of 37 expressions that express what the writer thinks, feels, and behaves while writing a text. These expressions are scored based on a 5-point rating scale involving the options "not at all true of me, not true of me, moderately true of me, true of me and very true of me". WSS is a single factor scale with 37 items and does not consist of any reverse coded items. Kaiser-Meyer-Olkin (KMO) Test value was calculated to be .95 and the Cronbach alpha reliability coefficient was calculated as .96. These values are accepted as indicators that the scale is a reliable data collection tool. The inventory included items such as "I pay attention to the organization of the texts, i.e. relationship between sentences and paragraphs, I read in order to use in my writings", "I make a new paragraph when I move on to a different aspect of the topic while writing" "While writing, I choose words that are appropriate for the reader's age and education level", "If I think that the meaning of a sentence will not be understood, I change it", "I check whether the text has the characteristics of its type (e.g. essay, story, article, etc.)", "I pay attention to having a logical link among the sentences in the text.", "If another person/institution has given the topic of the text I will write on, I pay attention to staying on that topic", "I check the text I have written in terms of its tone (styles with a psychological effect such as didactic, dignifying, insulting styles).

The KMO value of the dataset was calculated to determine the suitability of the dataset for analysis. A KMO value above 0.80 indicates that it is suitable for factor analysis. $\mathrm{KMO}$ value of the scale is calculated as 0.95 in the current study.

Making correct decisions about individuals in measurement and evaluation depends on the accuracy of collected information while the accuracy of information depends on the validity and reliability of the measuring tool (Uyumaz \& Çokluk, 2016). For this reason, Cronbach Alpha reliability coefficients and Composite reliability of WSS were calculated. According to Özdamar (1999), if the Cronbach Alpha internal consistency coefficient of the scale is in the range of .80 $\leq<<1.00$, the scale is highly reliable.

Composite reliability represents an index reflecting the impact of error upon the scale. High reliability is a necessary condition for high validity, and an important prerequisite for applications of scale scores that are frequently used for purposes of 
behavioral assessment (Raykov\&Grayson,2003). Composite reliability is used to measure the general reliability of multiple, heterogeneous, but similar statements (Raykov, 1998). Standardized factor loadings of items, average variance extracted (AVE) values explained by dimensions in the scale greater than .50, composite reliability (CR) coefficients greater than .70 (Nunnally and Bernstein, 1994; Raykov,1998) and also the CR coefficients must be greater than the AVE values (Byrne, 2016). Table 1 shows the scale's Cronbach's alpha, combined reliability coefficients, average variance values

Table 1. Cronbach Alpha, composite reliability, extracted mean variance of the writing sensitivity scale

\begin{tabular}{ccccc}
\hline Number of Items & $\mathbf{N}$ & $\boldsymbol{\alpha}$ & AVE & CR \\
\hline 37 & 575 & .945 & .588 & .95 \\
\hline
\end{tabular}

In addition, confirmatory factor analysis was performed to confirm the single-factor structure of the scale for this study group. Although there is no consensus on which of the suggested fit indices should be reported in the literature, it is seen that different fit indices such as RMSEA CFI, GFI, NFI, NNFI, SRMR values are used (Brown,2006; Hooper, Coughlan \& Müllen,2008; Garver \& Mentzer, 1999; Gerbing \& Anderson, 1992; Iacobucci, 2010; Joreskog \& Sörbom, 2001; McDonald \& Moon-Ho, 2002; Schermelleh-Engel, Moosbrugger \& Müller, 2003; Tabachhnick \& Fidell,2001; Kutluca Canbulat,2020). It was found that the fit indices obtained as a result of the confirmatory factor analysis of the scale were compatible with the acceptance cut-off points. Within the scope of confirmatory factor analysis for WSS; the fit index values and fit levels recommended to be used are given in Table 2.

Table 2. Goodness of fit indices of the writing sensitivity scale

\begin{tabular}{lll}
\hline WSS & Fit Index & Cut-off values \\
\hline RMSEA & .06 & $0=$ Absolute fit $\leq .10=$ Weak fit \\
$\mathbf{X}^{2} / \mathbf{d f}$ & 3.5 & $\leq 2.5=$ Absolute $\leq 5=$ Moderate Fit \\
NFI & .95 & $\geq .90=$ Good fit \\
CFI & .97 & $\geq .95=$ Absolute fit \\
SRMR & .04 & $\leq .08=$ Good fit \\
NNFI & .97 & $\geq .90=$ Good fit \\
\hline
\end{tabular}

Rubric for Written Texts (RWT). Rubric for written text, developed by Ülper (2008) to score the written texts produced by the participants consists of five sub-sections such as "Creating the Content of the Text (WA1)", "Ability to Construct the Text Consistently $\left(W A_{2}\right) "$, "Using Accurate Lexicon for Effective Expression (WA3)", "Ability to Construct Appropriate Sentences for Effective Expression (WA4)" and "Applying the Mechanical 
Properties of the Text Accurately $\left(W A_{5}\right)^{\prime \prime}$. The criteria related to the textual actions specified in the scale are evaluated and scored in three stages as "insufficient (1)", "acceptable (2)" and "sufficient (3)".

The rubric included textual actions to be observed in individuals' writings such as "Writing the defences (thesis) of the text", "Linking the conclusion with previous parts of the text", "Choosing the suitable words and use on site" "Correct application of punctuation rules"

In the present study, the Cronbach Alpha reliability coefficient of the data collection tool was calculated as 0.96 .

The interrater consistency was determined by the Kendal W test which is used to determine the level of agreement in the scores provided by two or more raters. Table 3 presents the test results.

Table 3. Kendal $W$ test results

\begin{tabular}{llll}
\hline & W & df & p \\
\hline Inter-rater agreement & .808 & 14 & .002 \\
\hline
\end{tabular}

Table 3 points to a high agreement (Howell;1997: Kutlu, Doğan, \& Karakaya, 2010) among the three raters in the scores for 15 students.

\section{Data Analysis}

The normality of the distribution of the total scores obtained from the scales was examined. Table 4 presents the descriptive statistics regarding the total scores.

Table 4. Descriptive statistics

\begin{tabular}{lrrrrrrr}
\hline & WStotal & WAtotal & WAttotal & WA2total & WA3total & WAtotal & WAstotal \\
\hline $\mathbf{N}$ & 575 & 575 & 575 & 575 & 575 & 575 & 575 \\
Mean & 145,28 & 59,49 & 10,71 & 17,17 & 8,36 & 15,04 & 8,21 \\
Median & 145,00 & 60,00 & 11,00 & 17,00 & 9,00 & 15,00 & 8,00 \\
Mode & 140,00 & 65,00 & 11,00 & 17,00 & 9,00 & 16,00 & 8,00 \\
Std. deviation & 18,26 & 10,07 & 2,81 & 3,09 & 1,87 & 1,97 & 2,14 \\
Variance & 333,45 & 101,42 & 7,88 & 9,57 & 3,48 & 3,88 & 4,58 \\
Skewness &,- 114 &,- 215 &, 208 &,- 139 &,- 238 &,- 881 &,- 211 \\
Std. Error of Skewness &, 102 &, 102 &, 102 &, 102 &, 102 &, 102 &, 102 \\
Kurtosis &,- 020 &, 093 &, 054 &, 292 &, 078 &, 663 &,- 385 \\
Std. Error of Kurtosis &, 203 &, 203 &, 203 &, 203 &, 203 &, 203 &, 203 \\
Range & 98,28 & 56,00 & 16,00 & 16,00 & 9,00 & 9,00 & 10,00 \\
Minimum & 86,72 & 28,00 & 3,00 & 8,00 & 3,00 & 9,00 & 2,00 \\
Maximum & 185,00 & 84,00 & 19,00 & 24,00 & 12,00 & 18,00 & 12,00 \\
\hline
\end{tabular}

Analysis of Table 4 demonstrates that the mean, mode, and median had values close to one another and that the skewness and kurtosis coefficients remain within the limit 
of \pm 1 . This is an indication that the distributions did not deviate from the normal distribution. In addition, in order to test the normal distribution, if the group size is greater than 50, the Kolmogorov-Smirnov Test results are examined (Büyüköztürk, 2006). The significance value for the WSS Kolmogorov-Smirnov test was calculated as .20 , and the significance value for the RWT as .06. If the calculated value is greater than .05 , it is interpreted that the distribution does not deviate from the normal distribution (Büyüköztürk, 2006) Since the data set normally distributed parametric tests were used in the later stages of the study based on these findings.

Pearson Product-Moment correlation coefficient was used to examine the correlations between the scores that the participants obtained from the relevant scales to seek answers to the first three sub-objectives of the study. Differences based on gender were determined by using independent samples $t$-test and differences based on school year were determined by using the one-way analysis of variance (ANOVA).

\section{Findings}

\section{Findings Related to the First Research Question}

Descriptive statistics were used to answer the first research question.

Table 5. Descriptive statistics for writing sensitivity and writing achievement levels

\begin{tabular}{lccccc}
\hline & N & Minimum & Maximum & Mean & SD \\
\hline WStotal & 575 & 86,72 & 185,00 & 145,28 & 18,26 \\
WAtotal & 575 & 28,00 & 84,00 & 59,49 & 10,07 \\
\hline
\end{tabular}

Table 5 shows that writing sensitivity scores of teacher candidates changed between 86,72 and 185,00 with a mean of 145,28 . The standard deviation was found to be 18,26 . On the other hand, it was found that teacher candidates' writing achievement scores ranged between 28,00 to 84,00 and that the mean score was 59,49 . The standard deviation was found to be 10,07 .

\section{Findings Related to the Second Research Question}

The second research question was addressed in two sub-dimensions.

\subsection{Differences in primary school teacher candidates' writing sensitivity by gender.}

The first sub-dimension of the second asked whether the writing sensitivity of primary school teacher candidates differed by gender. Table 6 presents the results of the independent samples $t$-test conducted to answer this research question. 
Table 6. Differences in writing sensitivity by gender

\begin{tabular}{cccccccc}
\hline & Gender & $\mathbf{N}$ & $\overline{\boldsymbol{X}}$ & $\mathbf{S D}$ & $\mathbf{t}$ & $\mathbf{d f}$ & $\mathbf{p}$ \\
\hline WStotal & Male & 161 & 139,76 & 18,82 & 4,596 & 573 & .000 \\
& Female & 414 & 147,43 & 17,60 & & & \\
\hline & Total & 575 & & & & & \\
\hline
\end{tabular}

Table 6 shows that teachers candidates' writing sensitivity significantly differed according to gender. It was found that female teacher candidates' writing sensitivity was statistically higher than male teacher candidates' writing sensitivity. The effect size of the difference between the groups (eta square $=\eta 2$ ) was calculated as .03. There is a small effect if the eta square value is between .01-.06 (Akbulut, 2010, Kilmen,2015). According to the calculated effect size, gender has a small effect on writing sensitivity.

2.2. Differences in primary school teacher candidates' writing sensitivity according to the school year.

The second sub-dimension asked whether the writing sensitivity of primary school teacher candidates differed according to the school year. Table 7 presents the results of the one-way analysis of variance (ANOVA) conducted to answer this research question.

Table 7. Differences in writing sensitivity by school year

\begin{tabular}{llllllll}
\hline & $\mathbf{N}$ & Mean & SD & df & F & P & Difference \\
\hline $\mathbf{1}^{\text {st }}$ year & 147 & 148,80 & 18,15 & $3-571$ & 2,519 & .057 & - \\
$\mathbf{2}^{\text {nd }}$ year & 141 & 143,70 & 16,81 & & & & \\
$\mathbf{3}^{\text {rd }}$ year & 137 & 144,59 & 17,23 & & & & \\
$\mathbf{4}^{\text {th }}$ year & 150 & 143,95 & 20,22 & & & & \\
Total & 575 & 145,28 & 18,26 & & & & \\
\hline
\end{tabular}

As seen in Table 7, the primary school teacher candidates' writing sensitivity does not significantly differ by the school year.

\section{Findings Related to the Third Research Question}

The third research question was addressed in two sub-dimensions.

\subsection{Differences in primary school teacher candidates' writing achievement by gender.}

The first sub-dimension of the third research question investigated whether the primary school teacher candidates' writing achievement differed by gender. Table 8 presents the results of the independent samples $t$-test conducted to answer this research question. 
Table 8. Differences in writing achievement by gender

\begin{tabular}{cccccccc}
\hline & Gender & $\mathbf{N}$ & $\overline{\boldsymbol{X}}$ & SD & $\mathbf{t}$ & $\mathbf{d f}$ & $\mathbf{p}$ \\
\hline WAtotal & Male & 161 & 55,81 & 10,39 & 5,612 & 573 & .000 \\
& Female & 414 & 60,92 & 9,58 & & & \\
\hline Total & 575 & \multicolumn{1}{c}{} & & & \\
\hline
\end{tabular}

Table 8 reveals that the primary school teacher candidates' writing achievement significantly varied according to gender. Female teacher candidates' writing achievement was found to be significantly higher than male teacher candidates' writing achievement. The effect size of the difference between the groups (eta square $=\eta 2$ ) was calculated as 0.05 . According to the calculated effect size, gender has a small effect on writing achievement.

\subsection{Differences in primary school teacher candidates' writing achievement by school year.}

The second sub-dimension of the third research investigated whether the primary school teacher candidates' writing achievement differed by the school year. Table 9 presents the results of the one-way analysis of variance (ANOVA) conducted to answer this research question.

Table 9. Differences in writing achievement by school year

\begin{tabular}{lllllllr}
\hline & $\mathbf{N}$ & Mean & SD & df & F & P & Difference \\
\hline $\mathbf{1}^{\text {st }}$ year & 147 & 55,45 & 10,06 & $3-571$ & 16,614 & .000 & $1-3$, \\
$\mathbf{2}^{\text {nd }}$ year & 141 & 58,49 & 10,57 & & & & $1-4$ \\
$\mathbf{3}^{\text {rd }}$ year & 137 & 61,08 & 8,80 & & & & $2-4$ \\
$\mathbf{4}^{\text {th }}$ year & 150 & 62,94 & 9,20 & & & & \\
Total & 575 & 59,49 & 10,07 & & & & \\
\hline
\end{tabular}

Table 9 demonstrates that primary school teacher candidates' writing achievement significantly varied according to the school year. Levene's test, which tests the homogeneity of variances, was calculated as ,067. A significance value greater than 0,05 indicates homogeneity of variances (Kilmen,2015). For this reason, the Schefe test, which is one of the post-Hoc tests used when the variances are equal, was used to determine the difference between the groups. According to the test values writing achievement of fourth-year teacher candidates was found to be higher than the writing achievement of both first-year and second-year teacher candidates in a statistically significant manner. In addition, the writing achievement of third-year teacher candidates was higher than the writing achievement of first-year teacher candidates in a statistically significant manner. The effect size of the difference between the groups 
(eta square $=\eta 2$ ) was calculated as 0.08. According to the calculated effect size, the school year has a medium effect on writing achievement.

\section{Findings Related to the Fourth Research Question}

The fourth research question asked whether primary school teacher candidates' writing achievement levels differ based on their writing sensitivity?". The cut points were determined by adding and subtracting 0.5 standard deviation to and from the scale total mean score to classify the primary school teacher candidates' writing sensitivity levels as low (1), medium (2) and high (3) according to the writing sensitivity scale scores. Accordingly, the score range of teacher candidates with low sensitivity was 37-136; the score range of teacher candidates with medium sensitivity was 136.1-154 the score range of teacher candidates with high sensitivity was 154.1185. Table 10 presents the results of the one-way analysis of variance (ANOVA) conducted to answer this research question.

Table 10. Differences in writing achievement by writing sensitivity

\begin{tabular}{lccccccc}
\hline & $\mathbf{N}$ & Mean $^{*}$ & SD & df & F & P & Difference \\
\hline $\mathbf{1}$ & 147 & 57,51 & 10,30 & $2-570$ & 4,501 & .012 & $1-2$, \\
$\mathbf{2}$ & 141 & 60,21 & 9,91 & & & & $1-3$ \\
$\mathbf{3}$ & 137 & 60,34 & 9,84 & & & & \\
Total & 575 & 59,45 & 10,07 & & & & \\
\hline
\end{tabular}

* Writing Achievement

Table 10 demonstrates that the primary school teacher candidates' writing achievement differed according to their writing sensitivity levels. Levene's test, which tests the homogeneity of variances, was calculated as .770. A significance value greater than 0,05 indicates homogeneity of variances (Kilmen,2015). For this reason, the Schefe test, which is one of the post-Hoc tests used when the variances are equal, was used to determine the difference between the groups. Writing achievement of primary school teacher candidates with a moderate and high level of sensitivity was found to be significantly higher than the writing achievement of primary school teacher candidates with low writing sensitivity. The effect size of the difference between the groups (eta square $=\eta 2$ ) was calculated as .01. According to the calculated effect size, writing sensitivity level has a small effect on writing achievement. 


\section{Findings Related to the Fifth Research Question}

The fifth research question asked whether primary school teacher candidates' writing achievement scores in the sub-dimensions of the Rubric for Written text differed based on gender and school year. This research question was addressed in two subdimensions.

\subsection{Differences in Sub-Dimension Scores of Writing Achievement Scale by Gender}

The first sub-dimension of the fifth research question investigated whether primary school teacher candidates' writing achievement scores in the sub-dimensions of the Rubric for Written text differed based on gender. Table 11 presents the results of the independent samples $t$-test conducted to answer this research question.

Table 11. Differences in sub-dimension scores of the rubric for written text by gender

\begin{tabular}{|c|c|c|c|c|c|c|c|}
\hline & Gender & $N$ & $\bar{X}$ & SD & $\mathbf{t}$ & df & $\mathbf{p}$ \\
\hline \multirow[t]{2}{*}{ WA1total } & Male & 161 & 10,14 & 2,91 & 3,059 & 573 & .002 \\
\hline & Female & 414 & 10,93 & 2,74 & & & \\
\hline \multirow[t]{2}{*}{ WA2total } & Male & 161 & 16,16 & 3,25 & 4,987 & 573 & .000 \\
\hline & Female & 414 & 17,57 & 2,94 & & & \\
\hline \multirow[t]{2}{*}{ WA3total } & Male & 161 & 7,92 & 1,90 & 3,582 & 573 & .000 \\
\hline & Female & 414 & 8,53 & 1,83 & & & \\
\hline \multirow[t]{2}{*}{ WA4total } & Male & 161 & 14,45 & 2,03 & 4,516 & 573 & .000 \\
\hline & Female & 414 & 15,27 & 1,90 & & & \\
\hline \multirow[t]{2}{*}{ WA5total } & Male & 161 & 7,13 & 2,15 & 7,907 & 573 & .000 \\
\hline & Female & 414 & 8,62 & 1,99 & & & \\
\hline
\end{tabular}

Table 11 demonstrates that primary school teacher candidates' writing achievement scores differed according to gender. It was concluded that female teacher candidates' scores in the sub-dimensions of the Rubric for Written Text were higher than male teacher candidates' scores.

\subsection{Differences in Sub-Dimension Scores of Writing Achievement Scale by School Year}

The second sub-dimension of the fifth research question investigated whether primary school teacher candidates' writing achievement scores in the sub-dimensions of the Rubric for Written text differed based on the school year. Table 12 presents the results of the one-way analysis of variance (ANOVA) conducted to answer this research question. 
Table 12. Differences in sub-dimension scores of the rubric for written text by school year

\begin{tabular}{|c|c|c|c|c|c|c|c|c|}
\hline & & $\mathbf{N}$ & Mean & SD & $\mathrm{df}$ & F & p & Difference \\
\hline \multirow[t]{5}{*}{ WA1total } & 1 & 147 & 9,90 & 2,77 & $3-570$ & 10,159 & .000 & $1-3$ \\
\hline & 2 & 141 & 10,37 & 2,99 & & & & $1-4$ \\
\hline & 3 & 137 & 11,05 & 2,60 & & & & $2-4$ \\
\hline & 4 & 150 & 11,53 & 2,60 & & & & \\
\hline & Total & 575 & 10,71 & 2,81 & & & & \\
\hline \multirow[t]{5}{*}{ WA2total } & 1 & 147 & 16,16 & 3,15 & 3-570 & 12,976 & .000 & $1-3$ \\
\hline & 2 & 141 & 16,87 & 3,22 & & & & 1-4, \\
\hline & 3 & 137 & 17,38 & 2,76 & & & & $2-4$ \\
\hline & 4 & 150 & 18,27 & 2,84 & & & & \\
\hline & Total & 575 & 17,17 & 3,09 & & & & \\
\hline \multirow[t]{5}{*}{ WA3top } & 1 & 147 & 7,62 & 2,15 & $3-570$ & 20,311 & .000 & 1-3, \\
\hline & 2 & 141 & 8,01 & 1,66 & & & & 1-4, \\
\hline & 3 & 137 & 8,74 & 1,53 & & & & $2-3$, \\
\hline & 4 & 150 & 9,07 & 1,69 & & & & $2-4$ \\
\hline & Total & 575 & 8,36 & 1,87 & & & & \\
\hline \multirow[t]{5}{*}{ WA4total } & 1 & 147 & 14,35 & 2,18 & 3-570 & 12,904 & .000 & $1-3$ \\
\hline & 2 & 141 & 14,82 & 2,11 & & & & $1-4$ \\
\hline & 3 & 137 & 15,34 & 1,74 & & & & $2-4$ \\
\hline & 4 & 150 & 15,63 & 1,54 & & & & \\
\hline & Total & 575 & 15,04 & 1,97 & & & & \\
\hline \multirow[t]{5}{*}{ WA5total } & 1 & 147 & 7,42 & 1,85 & 3-570 & 9,340 & .000 & $1-2$, \\
\hline & 2 & 141 & 8,42 & 2,35 & & & & $1-3$ \\
\hline & 3 & 137 & 8,56 & 1,97 & & & & $1-4$ \\
\hline & 4 & 150 & 8,45 & 2,17 & & & & \\
\hline & Total & 575 & 8,21 & 2,14 & & & & \\
\hline
\end{tabular}

Table 12 shows that primary school teacher candidates' writing achievement scores in the sub-dimensions of the Rubric for Written text significantly differed according to the school year. To determine the difference between the groups Scheffe test was used, which is one of the post-Hoc tests used in case of equal variances. Primary school teacher candidates attending their $4^{\text {th }}$ year at the university had higher scores than both $1^{\text {st }}$ and $2^{\text {nd }}$-year students in a statistically significant manner in the following subdimensions: a) creating the content of the text, b) constructing the text consistently, c) correct use of vocabulary for effective expressions and $d$ ) establishing accurate sentences for effective expression. In addition, primary school teacher candidates attending their $3^{\text {rd }}$ year at the university had higher scores than $1^{\text {st }}$-year students in a statistically significant manner in creating the content of the text, constructing the text consistently and establishing accurate sentences for effective expression. Primary 
school teacher candidates attending their $3^{\text {rd }}$ year at the university had higher scores than both $1^{\text {st }}$ and $2^{\text {nd }}$-year students in a statistically significant manner in correct use of vocabulary for effective expressions. Also, it was found that primary school teacher candidates attending their $2^{\text {nd }}, 3^{\text {rd }}$ and $4^{\text {th }}$ year at the university had higher scores than

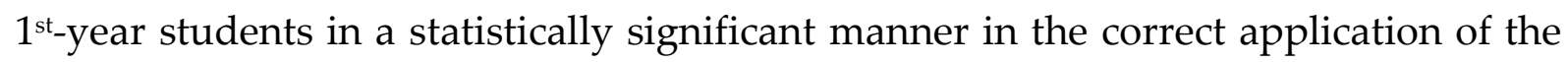
mechanical features of the text.

\section{Findings Related to the Sixth Research Question}

The sixth research question addressed within the scope of the research aimed to determine the relationship between the primary school teacher candidates' writing sensitivity and writing achievement. Pearson Product-Moment correlation coefficient was used to examine the relationship between the total scores obtained from the scales by primary school teacher candidates. Table 13 presents the relevant values.

Table 13. The relationship between writing sensitivity and writing achievement

\begin{tabular}{llr}
\hline & & Mtotal \\
\hline WS total & Pearson Correlation Coefficient &, $146^{* *}$ \\
& $\mathrm{p}$ &, 000 \\
& $\mathrm{~N}$ & 575 \\
\hline
\end{tabular}

Table 17 shows a low level, statistically significant relationship between primary school teacher candidates' writing sensitivity and their writing achievement.

\section{Findings Related to the Seventh Research Question}

The seventh research question addressed within the scope of the research sought answers about the relationship between primary school teacher candidates' writing sensitivity and their scores in the sub-dimensions of the writing achievement rubric. Pearson Product-Moment correlation coefficient was used to examine the relationship between the total scores obtained from the scales by the participants. Table 14 presents the relevant values.

Table 14. The relationship between writing sensitivity and the sub-dimensions of writing achievement

\begin{tabular}{llrrrrr}
\hline & & WA1total & WA2total & WA3total & WA4total & WA5total \\
\hline \multirow{3}{*}{ WS total } & Pearson C.C. & $.115^{* *}$ & $.106^{*}$ & $.135^{* *}$ & $.125^{* *}$ & $.148^{* *}$ \\
& $\mathrm{p}$ & .006 & .011 & .001 & .003 & .000 \\
& $\mathrm{~N}$ & 575 & 575 & 575 & 575 & 575 \\
\hline
\end{tabular}

Table 14 demonstrates a low level of a statistically significant relationship between primary school teacher candidates' writing sensitivity and their writing achievement scores in the sub-dimensions of the Rubric for Written text. 


\section{Conclusion, Discussion and Suggestions}

Individuals have their first writing experiences with their primary school teachers who have a crucial role in developing and improving their writing skills. In this process, teachers can play an active role in enabling students to become competent writers by providing them with an interactive learning-teaching environment with sufficient instructional support when necessary that will enable them to experience the writing process (Cavkaytar, 2010). primary school teachers' competencies to help their students in the writing process indicate how their students will manage their writing processes in the future. If the primary school teacher is competent in writing skills and in how to carry out writing practices in class, students' writing experiences can also develop in a manner that is directly proportional to the competence of the teacher. primary school teachers' competencies in writing are thought to be related to their preservice acquisitions, their experiences, and their sensitivity to writing. Sensitivity means that the individual knows all the elements of a task from the beginning to the process of completion, has the knowledge and follows all steps carefully in implementation. Having a text with desired qualities may be associated with the writer's sensitivity that is observed in his/her diligence to planning, drafting, checking the content, looking at the spelling rules and rewriting. For this reason, this study examined the relationship between the primary school teacher candidates' writing sensitivity and writing achievements, which will lay the foundation for students' writing skills and improve them immensely.

According to the research findings.

a) It can be argued that the primary school teacher candidates have moderate writing sensitivity and writing achievement based on the mean scores they received from the Writing Sensitivity Scale and the Rubric for Written Texts.

b) It was found that primary school teacher candidates' writing sensitivity and writing achievements significantly differed according to gender and that the writing sensitivity and writing achievement of female teacher candidates were higher than the writing sensitivity and writing achievement of male teacher candidates in a statistically significant manner. Similarly, it was found that Turkish teacher candidates' attitude scale scores towards writing education courses showed a significant difference according to gender and female teacher candidates had a more positive attitude towards the course than male teacher candidates (Ceran, 2013). Zorbaz's (2010) research on secondary school students indicated that students' 
writing anxiety significantly differed according to gender. Accordingly, Zorbaz found that female students' writing anxiety was lower than that of male students and the difference between female and male students was statistically significant. This finding can be interpreted that female students are more likely to write and relate to writing compared to male students (Ceran, 2013).

c) It was found that primary school teacher candidates' writing sensitivity did not differ significantly according to school year while writing achievement significantly varied based on the school year. Compared to the $1^{\text {st }}$ and $2^{\text {nd }}$ year teacher candidates, writing achievement of the teacher candidates in the $4^{\text {th }}$ year was higher in a statistically significant manner. In addition, the writing achievement of the teacher candidates in their $3^{\text {rd }}$ year was higher in a statistically significant manner than the writing achievement of teacher candidates in their first year. In their study on metacognitive awareness by school year, Baysal, Ayvaz, Çekirdekçi and Malbeleği (2013) found that metacognitive awareness was significantly higher in $4^{\text {th }}$-year teacher candidates compared to $1^{\text {st-year }}$ teacher candidates in terms of total scores. They explained this finding by stating that compared to $1^{\text {st }}$ year teacher candidates, $4^{\text {th }}$-year teacher candidates were able to think more in-depth about cognitive abilities and activities and they were more aware of their characteristics and the characteristics of the given task.

d) It was found that primary school teacher candidates' writing achievement varied according to their writing sensitivity levels. Writing achievement of teacher candidates with moderate and high writing sensitivity was found to be higher in a statistically significant manner than the writing achievement of teacher candidates with low writing sensitivity levels.

e) It was observed that primary school teacher candidates' scores in creating the content of the text, constructing the text consistently, correct use of vocabulary for effective expressions, establishing accurate sentences for effective expression, and correct application of the mechanical features of the text significantly differed according to gender. Female primary school teacher candidates' scores in the subdimensions of the writing achievement rubric such as creating the content of the text, constructing the text consistently, correct use of vocabulary for effective expressions, establishing accurate sentences for effective expression, and correct application of the mechanical features of the text were significantly higher than those of their male counterparts.

f) It was observed that primary school teacher candidates' scores in writing achievement rubric sub-dimensions (creating the content of the text, constructing the 
text consistently, establishing accurate sentences for effective expression, and correct application of the mechanical features of the text) significantly differed according to the school year. Compared to $1^{\text {st }}$ and $2^{\text {nd }}$-year teacher candidates, the scores of $4^{\text {th }}$-year teacher candidates in a) creating the content of the text, b) constructing the text consistently, c) correct use of vocabulary for effective expressions and d) establishing accurate sentences for effective expression. In addition, teacher candidates attending

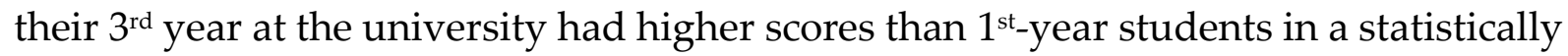
significant manner in creating the content of the text, constructing the text consistently and establishing accurate sentences for effective expression. Teacher candidates attending their $3^{\text {rd }}$ year at the university had higher scores than both $1^{\text {st }}$ and $2^{\text {nd }}-$ year students in a statistically significant manner in correct use of vocabulary for effective expressions. Also, it was found that teacher candidates attending their $2^{\text {nd }}, 3^{\text {rd }}$ and $4^{\text {th }}$

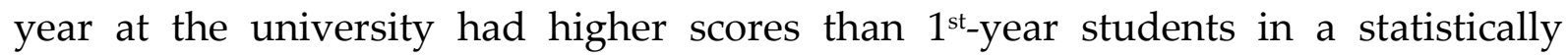
significant manner in the correct application of the mechanical features of the text.

g) A low level, statistically significant relationship was observed between primary school teacher candidates' writing sensitivity and their writing achievement. However, primary school teacher candidates' writing achievement differed according to their writing sensitivity levels. Writing achievement of primary school teacher candidates with a moderate and high level of sensitivity was found to be significantly higher than the writing achievement of primary school teacher candidates with low writing sensitivity.

h) A low level, statistically significant relationship was found between primary school teacher candidates' writing sensitivity and the following sub-dimensions of the writing achievement scale: creating the content of the text, constructing the text consistently, correct use of vocabulary for effective expressions, establishing accurate sentences for effective expression, and correct application of the mechanical features of the text. The reason why these low correlation coefficients are significant may be the number of samples.

An individual with writing sensitivity is expected to know the purpose of the text before starting to write, determine what he/she knows and does not know about the subject, estimate the required time to write, and be aware that he/she may need to do research when necessary, plan the writing and create a draft, i.e., how to start writing, how to develop this/her writing by using specific elements and features and how to terminate the text. After these steps, the individual is expected to start writing, review what is written and correct where necessary and be diligent to act in accordance with 
what he/she know during the process of writing (Bayat \& Şekercioğlu, 2014). Careful attention to the writing process can also lead to successful writings. Therefore, it was expected that there would be a higher relationship between writing sensitivity and writing achievement, but it was found that a low level of a statistically significant relationship between primary school teacher candidates' writing sensitivity and their writing achievement scores. This finding may be related to the fact that teacher candidates could not transform their writing sensitivity into writing performance. Writing sensitivity is related to the individual's metacognitive awareness of the writing process. Metacognitive awareness includes the individual's being aware of what he knows or not, controlling his mental processes, taking responsibility for learning, being aware of his learning strategies, evaluating his learning, planning, monitoring, and using the strategies to manage his knowledge. Metacognition consists of two main components as cognitive knowledge and cognitive regulation. Schraw (1994) suggested that adult students may differ not so much in their metacognitive knowledge skills but in their metacognitive regulation skills. Similarly, Young \& Fry (2008), found that there was a positive relationship between metacognitive knowledge and academic achievement, but no positive relationship was found with metacognitive regulation skills. Therefore, the low level of relationship between teacher candidates' writing sensitivity and writing achievement may have been affected by their metacognitive regulation skill levels. Therefore, the relationship between writing achievement and metacognitive knowledge or/and metacognitive regulation skills can be investigated.

\section{References}

Bayat, N., \& Şekercioğlu, G. (2014). Defining the psychometric properties of the writing sensitivity scale and analysing writing sensitivity with regard to different variables. International Journal of Language Academy, 2 (3), 283-301. https://bit.ly/3z52L9A

Baysal, Z. N., Ayvaz, A., Çekirdekçi, S., \& Malbeleği, F. (2013). An analysis of metacognitive awareness of pre-service elementary classroom teachers in terms of various variables. MÜ Atatürk Faculty of Education Journal of Educational Sciences, 37, 6881. https://dergipark.org.tr/en/pub/maruaebd/issue/386/2556

Büyüköztürk, Ş (2006). Sosyal bilimler için veri analizi el kitabı: İstatistik, Araştırma

Deseni, SPSS Uygulamaları ve Yorum. Pegem Yayıncilı.

Cavkaytar, S. (2010). Benefitting from writing process method to improve written expression skills in primary education. Journal of International Social Research, 3(10), 133 139. https://bit.ly/3ep78ma 
Ceran, D. (2013). Turkish teachers' attitudes towards the evaluation of writing training $\begin{array}{llll}\text { course. Electronic Turkish } & \text { 8tudies, }\end{array}$ http://dx.doi.org/10.7827/TurkishStudies.4187

Dunsmuir, S., Kyriacou, M., Batuwitage, S., Hinson, E., Ingram, V., \& O'Sullivan, S. (2015). An evaluation of the Writing Assessment Measure (WAM) for children's narrative writing. Assessing Writing, 23, 18. https://doi.org/10.1016/j.asw.2014.08.001

Flower, L., \& Hayes, J. R. (1981). A cognitive process theory of writing. College Composition and Communication, 32(4), 365-387. https://doi.org/10.2307/356600

Güneş, F. (2014). Türkçe öğretimi yaklaşımlar ve modeller. Ankara: Pegem Academy Publishing.

Huot, B. (2003). Rearticulating writing assessment for teaching and learning. University Press of Colorado.

Karasar, N. (2011). Bilimsel Araştırma Yöntemleri. Nobel Yayınları.

Kaya, B., \& Ateş, S. (2016). The effect of process-based writing focused on metacognitive skills-oriented to fourth grade students' narrative writing skill. Education and Science, 41(187), 137-164. http://dx.doi.org/10.15390/EB.2016.6752

Kellog, R. T. (2008). Training writing skills: A cognitive developmental perspective journal of writing research. Department of Psychology, Saint Louis University.

Kutlu, Ö., Doğan, C.D., \& Karakaya, İ. (2010). Determining student success. (3 ${ }^{\text {rd }}$ Ed.). Ankara: Pegem Academy Publishing.

Kutluca Canbulat, A.N. (2020). Adaptation of writing feedback scale to Turkish. International Journal of Languages' Education and Teaching. 8(1), 20-36. http://dx.doi.org/10.29228/ijlet.41766

Lovorn, M. G., \& Rezaei, A. R. (2011). Assessing the assessment: Rubrics training for pre-service and new in-service teachers. Practical Assessment, Research, and Evaluation, 16(1), 16. https://doi.org/10.7275/sjt6-5k13

Özdamar, K. (1999). Paket programlarla istatistiksel veri analizi-1 (Statistical data analysis by custom softwares-1). Kaan Kitabevi.

Özsoy, G. (2008). Üstbiliş. Türk Ĕ̆itim Bilimleri Dergisi. 6(4), 713-740. https://dergipark.org.tr/tr/pub/tebd/issue/26110/275094

Özsoy, G., Ataman, A. (2009). The effect of metacognitive strategy training on mathematical problem- solving achievement. International Electronic Journal of Elementary Education, 1(2), 67-82. https:/files.eric.ed.gov/fulltext/ED508334.pdf 
Özsoy, G., Memiş, A., \& Temur, T. (2017). Metacognition, study habits and attitudes. International Electronic Journal of Elementary Education, 2(1), 154-166. https://www.iejee.com/index.php/IEJEE/article/view/263

Özsoy, G., \& Günindi, Y. (2011). Prospective preschool teachers' metacognitive awareness. Primary Education Online, 10(2), 430-440. https://www.ilkogretimonline.org/fulltext/218-1596869645.pdf?1640594505

Penner-Williams, J., Smith, T. E., \& Gartin, B. C. (2009). Written language expression: Assessment instruments and teacher tools. Assessment for Effective Intervention, 34(3), 162-169. https://doi.org/10.1177\%2F1534508408318805

Pressley, M., Graham, S., \& Harris, K. (2006). The state of educational intervention research as viewed through the lens of literacy intervention. British Journal of Educational Psychology, 76(1), 1-19. https://doi.org/10.1348/000709905X66035

Raykov, T., \& Grayson, D. (2003) A test for change of composite reliability in scale development. Multivariate Behavioral Research, 38(2), 143-159. https://doi.org/10.1207/S15327906MBR3802 1

Raykov, T. (1998). Coefficient alpha and composite reliability with interrelated nonhomogeneous items. Applied Psychological Measurement, 22(4), 375-385. https://psycnet.apa.org/doi/10.1177/014662169802200407

Ross-Fisher, R.L. (2005). Developing effective success rubrics. Kappa Delta Pi Record, 41 (3), 131-135. https://doi.org/10.1080/00228958.2005.10518823

Schraw, G. (1994). The effect of knowledge on local and global monitoring. Contemporary Educational Psychology, 19, 143-154. https://doi.org/10.1006/ceps.1994.1013

Schraw, G., \& Moshman, D. (1995). Metacognitive theories. Educational psychology review, 7(4), 351-371. https://doi.org/10.1007/BF02212307 Tomkins, M. (2003). Trouble comes in threes. Times Educational Supplement, 4547 (2003), 23-23.

Uyumaz, G., \& Çokluk, Ö. (2016). An investigation of item order and rating differences in likert-type scales in terms of psychometric properties and attitudes of respondents. Journal of Theoretical Educational Science, 9(3), 400-425. https://dergipark.org.tr/tr/pub/akukeg/issue/29363/314180

Ülper, H., \& Uzun, L. (2009). Effect of writing education programs prepared according to cognitive process model on success of students. Primary Education Online, 8(3), 651665 .

Ülper, H. (2008). The effects of teaching writing program prepared in accordance with cognitive process model on student achievement. [Unpublished doctoral dissertation]. Ankara University. 
Young, A., \& Fry, J. D. (2008). Metacognitive awareness and academic achievement in college students. Journal of the Scholarship of Teaching and Learning, 8(2), 1-10. https://eric.ed.gov/?id=E[854832

Zorbaz, K. Z. (2010). The relationship between middle school student's writing apprehension and blocking with their written expression skills [Unpublished doctoral dissertation]. Gazi University. 